\title{
Gótico brasileño: el cine de Walter Hugo Khouri y José Mojica Marins
}

\section{Brazilian Gothic: The Films of Walter Hugo Khouri and José Mojica Marins}

\section{Resumen}

Este artículo anhela conectar los conceptos de "terror" y "horror" propuestos por la novelista gótica Ann Radcliffe con películas de los directores brasileños Walter Hugo Khouri y José Mojica Marins. Se discute aquí cómo tales conceptos se manifiestan en el contexto nacional y en qué sentidos, comunicados con la repetición y la diferencia, las películas de Khouri y Mojica pueden considerarse expresiones de un gótico brasileño. Partiendo de elementos derivados de la crítica angloamericana, pero, destacando los diferentes significados que estos elementos adquieren en Brasil. Interpretar las películas brasileñas a la luz del gótico significa abordar el tema de la "construcción de significado" en la historia nacional, pues el gótico tiene el potencial de revivir viejos traumas y generar discusiones sobre contextos sociales específicos.

Palabras claves

Gótico; Cine; Walter Hugo Khouri; José Mojica Marins; Brasil.

\begin{abstract}
This paper seeks to connect the concepts of "terror" and "horror" proposed by Gothic novelist Ann Radcliffe to films by Brazilian directors Walter Hugo Khouri and José Mojica Marins. It will be discussed here how such concepts manifest themselves in the national context and in which senses, trapped somewhere between repetition and difference, Khouri and Mojica's films can be deemed expressions of a Brazilian Gothic. Stemming from elements derived from Anglo-American criticism, but, highlighting the different meanings that these elements gain in Brazil. To interpret Brazilian films in the light of the Gothic means addressing the issue of
\end{abstract}


"construction of meaning" in national history, as the Gothic has the potential to revive old traumas and generate discussions about specific social contexts.

Keywords

Gothic; Cinema; Walter Hugo Khouri; José Mojica Marins; Brazil.

\section{Introducción}

En su ensayo "On the Supernatural in Poetry" (1826), publicado en el periódico The New Monthly Magazine and Literary Journal, la escritora Ann Radcliffe hace una distinción entre terror y horror con el objetivo de establecer una división en la literatura gótica producida en ese período.

Terror y Horror son opuestos diametrales, el primero expande el alma y despierta las facultades hacia un grado más alto de la vida; el otro contrae, congela y casi las aniquila. Concibo que ni Shakespeare ni Milton en sus ficciones, ni el Sr. Burke en su raciocinio, jamás consideraron positivamente el horror como una fuente del sublime, entretanto, todos están de acuerdo que el terror es una forma elevada; $y$, ¿dónde reside la gran diferencia entre el terror y el horror, sino en la duda y oscuridad, que acompañan al primero, respetando el mal temido? (Radcliffe 6) ${ }^{1}$

Radcliffe argumenta que el terror se caracterizaría por la indeterminación y oscuridad en el tratamiento de eventos potencialmente tenebrosos, y que tales condiciones de incertidumbre elevarían el alma para esferas más altas de la vida. En contraste, las descripciones de atrocidades del horror congelarían el espíritu y

${ }^{1}$ En el original: "Terror and Horror are so far opposite, that the first expands the soul and awakens the faculties to a high degree of life; the other contracts, freezes and nearly annihilates them. I apprehend, that neither Shakespeare nor Milton by their fictions, nor Mr. Burke by his reasoning, anywhere looked to positive horror as a source of the sublime, though they all agree that terror is a very high one; and where lies the great difference between horror and terror, but in uncertainty and obscurity, that accompany the first, respecting the dreaded evil?". 
casi aniquilarían la capacidad de reaccionar del lector. En otras palabras, la autora defiende que, para generar el efecto de terror en la literatura, el escritor necesita un grado de indeterminación y de oscuridad en el uso del lenguaje y en el tratamiento del objeto, como condición necesaria para despertar la sensación de terror en los lectores.

Para ejemplificar tales argumentos ella cita a Shakespeare, a Milton, y las teorías estéticas de Edmund Burke, defendiendo que ese grado de indeterminación y oscuridad existente en el terror, abraza el potencial de despertar en los lectores el sentimiento del sublime - el que se caracteriza por el asombro frente a aquello que es grandioso. El objetivo de Radcliffe con ese ensayo sería definir sus elecciones literarias y, al mismo tiempo, cuestionar escenas de horror retratadas en la novela The Monk (1796), de Matthew Lewis, que sobremanera fue su rival literario en el siglo XVIII. Se conjetura que ella escribió la novela The Italian (1797) en respuesta al estilo más impactante de Lewis, inspirado en el Schauerroman alemán.

En 1957, Devendra P. Varma rescata la conceptualización de Radcliffe en el ámbito de la teoría y crítica literaria para clasificar las novelas de William Beckford, Charles Maturin y Mary Shelley como terror, y las de William Godwin y Matthew Lewis como horror. En 1969, Robert Hume también se vale de esa distinción, aunque con una diferencia muy tenue, añadiendo a la discusión la idea de que la novela de horror haría hincapié con elementos físicos y corporales, al paso que la novela de terror actuaría de modo más sugestivo y psicológico. En 1971, Robert Platzner cuestiona la rigidez de las categorías terror y horror de Hume, utilizando la novela The Mysteries of Udolpho (1794) para demostrar que la propia Radcliffe mezcló los conceptos en su obra.

Pese a que estos y otros teóricos hayan definido de diferentes modos los conceptos de terror y horror, contribuyendo para la comprensión que se tiene hoy sobre los términos, Ann Radcliffe fue la primera a hacer tal distinción en el contexto de la literatura gótica, su conceptualización permite pensar en posibilidades teóricas para revaluar y discutir algunos aspectos de la obra de los cineastas Walter Hugo Khouri y José Mojica Marins, ilustrando el eslabón entre la cultura brasileña y el 
gótico. En vez de simplemente "hacer una nueva clasificación" de los filmes de estos cineastas como góticos, el presente trabajo aborda reflexivamente las imágenes y representaciones que surgen en las películas, considerando sus orígenes y sus significados en el contexto nacional.

A primera vista, asociar las palabras Brasil y gótico puede parecer un oxímoron, apenas una combinación de palabras incongruentes, utilizadas de modo ingenioso para fines de un ejercicio crítico-teórico. Lo que ocurre es que, en el discurso de construcción de identidad nacional de Brasil, se afirma que este es un país esencialmente soleado y tropical, y esto se plantea en contradicción con la idea de tinieblas y sombras relacionadas con el gótico. Sin embargo, se argumenta aquí que hay una serie de eslabones capaces de unir estos conceptos aparentemente irreconciliables. Tal conexión tiene como base desdoblamientos y análisis socioculturales que se hicieron a partir de las situaciones de terror y horror presentes en narrativas góticas. En otras palabras, si bien el gótico brasileño se valga de ciertas convenciones narrativas características del gótico angloamericano, cuando estas situaciones son trasladadas o puestas en escena en el contexto brasileño, los efectos generados y las lecturas que se pueden hacer de las situaciones tienen significados específicos de la realidad nacional. Situadas en algún lugar entre imitación y diferencia, las situaciones góticas que se presentan nos obligan a cuestionar los dogmas de la historia y de las instituciones del país. En ello está la fuerza del gótico, el poder de conjurar fantasmas del pasado y despertar viejos traumas nacionales que la cultura y la historia oficial intentan ocultar.

\section{Las mansiones burguesas de Walter Hugo Khouri: espacios del gótico brasileño}

Algunas películas de Walter Hugo Khouri, a ejemplo de Estranho Encontro (1958), O Anjo da Noite (1974) y As Filhas do Fogo (1978), se pueden leer en la clave del gótico, pues utilizan convenciones narrativas y elementos escenográficos 
relacionados a ese modo discursivo, particularmente en lo que respeta al uso que el cineasta hace de mansiones localizadas en lugares yermos, en las que personajes en condiciones de aislamiento se envuelven en situaciones de transgresión social. El estilo lánguido de las películas y la atmósfera que insinúa una tragedia inminente, pero que nunca se desvela por completo, sugieren otras asociaciones con el gótico, en particular, con la definición de terror propuesta por Ann Radcliffe.

Khouri es considerado un director de sensibilidad única que abordó el malestar de la burguesía brasileña a través de temas afines a la literatura y a la filosofía (Pucci Jr. 20). Él es frecuentemente comparado a Ingmar Bergman y a Michelangelo Antonioni, cineastas cuyo interés por el Existencialismo les confiere un estatuto de "alta cultura". No obstante, tal interpretación de la obra de Khouri ni siempre funcionó en beneficio propio, y no es raro encontrar acusaciones de que sus filmes son muy complicados o que no tienen lazo con la realidad nacional brasileña. ${ }^{2}$ Se argumenta aquí que la burguesía que Khouri retrata, su mise-en-scène y sus elecciones estéticas no pueden ser otra cosa sino típicamente brasileñas. Además, debido al hecho de que sus filmes tienen como objeto de análisis la sociedad burguesa, es posible establecer mayores conexiones con el gótico a través de temas que caracterizan ese modo discursivo desde sus orígenes en el siglo XVIII, como el debate de cuestiones de clase social y preocupaciones raciales (Garret 44).

Khouri utiliza el tropo de la mansión antigua para articular circunstancias en las que los moradores y huéspedes de la casa se zambullan en situaciones propicias al crimen y a los amores ilícitos. Así como se pueden leer los castillos medievales y casas vitorianas en términos de una preocupación con privacidad y ocultamiento (Hogle 152; Bussing 100), las mansiones burguesas en Khouri son

${ }^{2}$ Estos argumentos difamatorios a menudo se basan en la afiliación de Khouri con la Companhia Cinematográfica Vera Cruz, fundada en São Paulo a fines de la década de 1940 para producir películas técnicamente sofisticadas de calidad internacional. Dado que esta propuesta no se correspondía con la agenda del Cinema Novo, que valoraba las producciones de bajo coste centradas en el debate de la realidad social subdesarrollada de Brasil, algunos críticos tienden a señalar que Khouri tenía poca relación con la historia del cine brasileño. El presente trabajo busca relativizar ese punto de vista, asociando el trabajo de Khouri con el género terror, una forma popular de cine. 
espacios que promueven, de forma literal y simbólica, ansiedades domésticas que se traducen en experiencias góticas. En este sentido, la mansión no es apenas un local donde acontece la actividad sobrenatural, pero se puede considerarla un verdadero personaje de la historia. Khouri emplea ese protocolo en varias de sus películas, logrando resultados que son específicos del contexto nacional brasileño.

Estranho Encontro presenta el problema del malestar burgués ambientado en una mansión. El cuerpo que desmaya en la escena de apertura es emblemático de la fragilidad física y mental de la protagonista Júlia (Andréa Bayard), cuyos surtos de pánico, amnesia y miedo del futuro remiten a las heroínas de Radcliffe, caracterizando lo que Ellen Moers llama de Female Gothic. ${ }^{3}$ Júlia intenta huir en la madrugada de su marido neurótico y carcelero, Hugo (Luigi Picchi) y se la rescata en una carretera desierta el bon-vivant, Marcos (Mário Sérgio), quien la lleva a una mansión imponente que pertenece a Wanda (Lola Brah), su amante más madura. Júlia pasa casi toda la película escondiéndose en los cuartos de la mansión laberíntica, intentando mantenerse oculta del mayordomo cínico (Sérgio Hinst) y de Wanda, que aparece sin aviso previo y, eventualmente, descubre su escondite. La principal escena da la película es el enfrentamiento entre el marido de Júlia y Wanda, que acaba poniéndose al lado de la joven. Leída bajo la luz de una masculinidad que se manifiesta de forma opresiva y violenta, el filme aborda cuestiones relacionadas con encarcelamiento femenino dentro del matrimonio y con el deseo de huir de la esfera doméstica.

En O Anjo da Noite, la joven estudiante de psicología, Ana (Selma Egrei), es contratada para ser niñera de dos niños durante la estadía de la familia en una mansión en Petrópolis. La dejan sola el fin de semana con el niño, la niña y el vigilante nocturno (Eliezer Gomes), Ana pasa a recibir llamadas misteriosas y amenazadoras. La situación se complica cuando el chico se enamora de la niñera.

${ }^{3}$ En 1977, Moers acuñó el término Female Gothic para designar narrativas cuyo papel central es protagonizado por las mujeres, como escritoras y personajes. Aunque ella no fue la primera en destacar el tema del género en los textos góticos, su objetivo era argumentar en contra de la posición de Robert Hume (1969), quien defendió la superioridad de la literatura de Matthew Lewis sobre la literatura de Ann Radcliffe. Últimamente se cuestiona de diferentes maneras la utilidad de esta división del gótico en distintas categorías, una masculina y una femenina. 
Ana no anhela seducirlo, su posición es amistosa, ella demuestra estar consciente del sofocante ambiente burgués donde los niños viven. Sin embargo, cuando el niño se rehúsa a dormir, el estado mental de Ana se deteriora y, para empeorar la situación, ella lo sorprende haciendo uno de los telefonazos amenazadores. En una escena simbólica de la tragedia que va a acontecer, Ana está al lado de una estatua de un ángel en tamaño humano, cuya espada levantada parece lista a decapitarla. En otra escena, Ana se tumba en el centro del salón principal de la mansión, prenunciando su muerte. El salón tiene un hermoso cielo raso de madera que, en este momento, se asemeja a una tapa de ataúd. Todas esas imágenes de muerte sugieren que Ana es un cuerpo extraño en la mansión, ella es oprimida por las fuerzas y por los conflictos que existen dentro de la casa, como si la mansión tuviese vida propia e influenciase sus habitantes.

No obstante, es en la figura del vigilante nocturno que se manifiestan las ambigüedades centrales de la película y los elementos góticos en el contexto nacional. Al inicio, se presenta el vigía como un hombre servil, cuya vida se enlaza con el local donde vive y con la familia que habita en la mansión. Con todo, durante el transcurrir del fin de semana, especialmente por la noche, él se vuelve cada vez más osado y asustador. En una escena que sugiere la locura del ambiente, el niño y el vigilante comienzan a jugar "polis y cacos" dentro de la casa: el chico usa su arma de juguete y el vigía su arma de verdad. El vigilante nocturno se convierte en el contrapunto de la niñera, que siempre intenta comportarse de modo equilibrado y ecuánime. Esa secuencia perturbadora culmina en un surto de violencia cuando, en un acceso de rabia, el vigilante nocturno los mata a todos.

El final puede parecer un cliché de una película de terror, sin embargo, el vigía interpretado por Eliezer Gomes es un actor negro. El resultado es que el título "el ángel de la noche” gana connotaciones metafóricas y metonímicas que reflejan conflictos de clases, estratificación social y étnica en la sociedad brasileña. La película de Khouri demuestra estar consciente sobre cómo incitar miedo en un público burgués, trabajando con determinadas posibilidades de peligro y amenaza relacionados con sus trabajadores domésticos. 
En última instancia, la elección de Eliezer Gomes para el papel del asesino desafía postulados sobre la naturaleza conciliadora de la sociedad brasileña, la que supuestamente buscó encortar distancias sociales y étnicas entre señores y esclavos desde los tiempos coloniales. En esta película, el gótico se manifiesta a partir del miedo generado por el otro racial y social, substituyendo al típico fantasma o monstruo como la fuente de ansiedad. El vigía desarrolla una percepción gradual, tal vez inconsciente, de la mediocridad que está condenado a ver y a vivir. La indiferencia de la burguesía en lo que toca a la angustia de las personas que viven al margen de la sociedad entra en erupción en el desenlace como ejemplo de una manifestación de un gótico brasileño.

As Filhas do Fogo pone en primer plano discursos de género y de nacionalidad, articulando preocupaciones sobre alteridades bajo la forma de una narrativa sobrenatural. En esta película, tres personajes femeninos vivencian eventos paranormales que acaban en muertes inexplicables. La asonancia en sus nombres (Ana, Diana, Mariana) sugiere que se pueden verlas como personajes interrelacionados o hasta incluso como un personaje tripartito que incorpora diferentes cuestiones referentes a la situación de mujeres en la sociedad. Más específicamente, una sociedad que condena la homosexualidad femenina (Ana), que prioriza la maternidad y el embarazo (relación problemática de Diana con su cuerpo) y que sanciona el aprisionamiento de mujeres en la esfera doméstica (Mariana).

La narrativa acontece en una comunidad no identificada al interior del Rio Grande do Sul y la fotografía destaca el clima más frío de la región, capturando imágenes de mañanas nebulosas y vegetación de clima templado. La composición visual también acentúa la herencia predominantemente europea, enseñando las caras pálidas de sus habitantes y la arquitectura germánica que trajo los inmigrantes. Tal representación intenta transmitir la idea de una sociedad pequeña aislada, una verdadera aldea extranjera en un área remota de Brasil, aún arraigada a sus orígenes y a su misticismo ancestral. Si, por un lado, esas imágenes destacan la ausencia de elementos tropicales (que son muchas veces asociados al territorio y a la identidad 
brasileña), por otro, ellas confieren a la película un carácter transnacional, pues tal ambientación ofrece una narrativa que funciona bien en diferentes contextos culturales.

El personaje Ana (Rosina Malbouisson), que es originariamente de la ciudad de São Paulo, describe el local como "bonito, pero no acogedor”, llevando el público hacia tu mirada. Ella se asusta con el paisaje del local (lagunas verdeoscuro, piedras cubiertas de musgo, vegetación que cuelga de los árboles) y con la forma como los moradores la miran, ojos que también parecen manifestarse en diferentes objetos. Ana viajó secretamente al Rio Grande do Sul para visitar a su novia Diana (Paola Morra), con la que le fue prohibido encontrarse, pues su familia descubrió cartas comprometedoras entre las dos. La relación lesbiana en As Filhas do Fogo es un elemento de transgresión que interfiere en el papel convencionalmente atribuido a las mujeres. La ansiedad y los deseos reprimidos de Ana son, de acuerdo con Pauline Palmer, “de importancia central para el individuo lesbiano que, en ausencia de una historia y de un lenguaje para expresar su orientación sexual, puede sentirse perseguido por emociones que no puede o no se atreve a articular" (Palmer 119). ${ }^{4}$ Secreto y silencio, además del sentimiento de desamparo emocional y comunicativo, son aspectos definidores de la angustia de Ana, los ojos vigilantes que ella nota en muchos objetos actúan como símbolos de los eventos que siguen.

Con el avance de la película, Diana se convierte en narradora, y el público gana una nueva perspectiva sobre la narrativa, sobre todo cuando ella comenta respecto de su afecto por aquel lugar remoto y por la mansión. Las dos mujeres se aman y también están unidas en lo que se refiere a las relaciones complicadas que ambas tienen con sus respectivas familias. El padre de Diana fue una figura ausente durante la mayor parte de su vida y su madre falleció cuando ella aún era niña. Luego la audiencia percibe que Diana nunca consiguió separarse completamente

\footnotetext{
${ }^{4}$ En el original: "of central importance to the lesbian subject who, lacking a history and a language to articulate her sexual orientation, may feel haunted by emotions which she cannot or dare not articulate".
} 
de la figura materna, cuya memoria se mantiene viva con la evocación de las historias antiguas y con el hojear de los álbumes de fotografía de la familia. Su foto favorita es la de su madre de vestido largo, sacada cuando ella estaba embarazada de Diana. En este sentido, nacimiento y muerte se concentran en la figura de la madre de Diana y, de manera en que ella persiste en su idea fija en relación con el embarazo de su madre, sus traumas se materializan en quejas, como el hecho de tener la constitución física morena como el padre - aun los otros personajes diciéndole que se asemeja mucho a su madre, incluso en lo que concierne a su sexualidad, como es revelado más tarde en la película. La conexión de Diana con la realidad se vuelve cada vez más tenue y ella comienza a hablar sobre las personas muertas en su familia como si estuviesen vivas. La única persona que parece darse cuenta de su estado mental atormentado es la ama de llaves, Mariana (Maria Rosa), una mujer de orígenes afro-amerindias que confiere un "color local" a aquel ambiente enteramente europeo.

Mariana trabaja como gobernanta en la mansión, pero a veces va más allá de su función como administradora de la casa, conversando con Diana como si fuese una hermana mayor. Aunque no haya escenas explícitas de sexo envolviendo a las tres mujeres, Diana le comenta sugestivamente a Ana que "Mariana tiene manos increíbles", y todas se ríen. Con todo, mientras Diana demuestra desprecio por el sexo masculino, declarando que "todos los hombres son vagos", Mariana hace el amor con un andariego que aparece en la mansión pidiendo comida y trabajo (con consecuencias que causan su muerte). La situación específica de Mariana habla de opresión femenina en una cultura que determina el confinamiento de las mujeres en la esfera doméstica. En una escena, ella declara que nació en la región y nunca salió de allí, raramente estuvo lejos de casa. Mariana parece aceptar su situación, y tal vez por ello sea la menos confusa de los tres personajes. Aparte de los temas de paranoia, ansiedad y muerte, el gótico emerge aquí en la figura de la mujer presa dentro del espacio doméstico (la dimensión privada como una extensión del femenino) y en el tropo de la mansión antigua localizada en un lugar siniestro, donde los sueños están destinados al fracaso. 
Los personajes femeninos pasan a ser asustados por el fantasma de la madre de Diana. A partir del momento en que las fronteras entre este mundo y el otro comienzan a mezclarse, secretos escandalosos de la familia comienzan a ser revelados. El desenlace es inexplicable y tiene aires de pesadilla: el exuberante bosque alrededor de la propiedad envuelve completamente la casa y sus moradores - Mariana es la única que escapa. Esa "vuelta a la naturaleza" da la posibilidad de una lectura que demuestra los destinos individuales de los personajes a la luz de una narrativa nacional. En otras palabras, es como si se reafirmara la historia de la construcción de la nación en el momento en que la vegetación domina la mansión.

Reconocer esa superposición entre las esferas personales y públicas en el filme significa retratar la esfera doméstica, centrada en el femenino, como una metonimia de la nación a través de homologías que interpretan la construcción de las vidas privadas como representantes de destinos públicos. Al pensar en el destino de la mansión, la cuestión del poder y de las fuerzas patriarcales opresoras que actúan sobre la psique femenina tripartita y sugieren que se puede leer la película como una metonimia del nacional, con características góticas. Interpretar las películas de Walter Hugo Khouri desde una perspectiva gótica motiva una revaluación de las obras que anteriormente fueron consideradas demasiadamente eruditas y complicadas.

\section{La violencia indómita de Zé do Caixão: misoginia, esclavitud y los sótanos de la dictadura}

Con sus uñas largas, sombrero de copa y capa negra, Zé do Caixão es un ícono del cine nacional. El sepulturero maldito fue inmortalizado en la trilogía $\grave{A}$ meia-noite levarei sua alma (1964), Esta noite encarnarei no seu cadáver (1968) y Encarnação do demônio (2008), entre otras películas, así como en programas de televisión y radio, comics y literatura de cordel. En 2015, él fue tema de una exposición en el Museu da Imagem e Som (MIS) de São Paulo, un homenaje a la 
influencia de ese personaje que ya se convirtió casi folclórico en Brasil. Zé do Caixão es un caso raro en la historia del cine brasileño de un personaje que es interpretado por su propio creador, el cineasta independiente José Mojica Marins. Muchas veces, Mojica se vale de esa particularidad para confundir al público, manipulando sus papeles para crear fusiones de identidad y otras formas de ambigüedad que contribuyen para aumentar la complexidad de la relación entre creador y criatura.

Su eslabón con el gótico aparece de forma más evidente en la utilización de un traje que está asociado a villanos de filmes de terror internacionales. Las ropas ostentosas de Zé do Caixão son ajenas al contexto brasileño, remitiendo a la moda de la Inglaterra Victoriana y a personajes como Mr. Hyde y Jack, el destripador. Más bien, son una contribución fundamental para la caracterización visual de Zé do Caixão, engrandeciendo al personaje. Inclusive, se puede pensar que Zé do Caixão no sería tan influyente o impactante sin su traje. Bajo una dinámica de los intercambios culturales, esa apropiación de un traje asociado al gótico victoriano sería un modo de capitalizar sobre el éxito de filmes extranjeros y de promover al personaje brasilero en asociación a íconos del cine de terror internacional. En otras palabras, en lugar de buscar verosimilitud histórica y social con el contexto brasileño, el director procura crear a través del traje un espectáculo cinematográfico a su audiencia.

Zé do Caixão aparece en las telas de cine por primera vez en el largometraje À meia-noite levarei sua alma. Tras asesinar a su esposa, Lenita (Valéria Vasquez), que él consideraba inapta para generar "el hijo perfecto", su deseo sexual se dirigirá hacia Terezinha (Magda Mei), novia de su mejor amigo, que se convierte en depositaria de su búsqueda por la perfección. Él asesina a su mejor amigo, Antonio (Nivaldo de Lima), ahogándolo en una bañera y, en seguida, viola a su novia. Deshonrada, Terezinha decide ahorcarse, pero antes lanza una maldición sobre Zé do Caixão, prometiendo volver del mundo de los muertos para llevarse su alma.

La escena de agresión y violación física de Terezinha es un ejemplo de crimen contra mujeres que, según Mary Ellen Snodgrass, constituye "El corazón 
palpitante del folclore gótico" (Snodgrass 118). ${ }^{5}$ La cena de la golpiza que ocurre antes de la violación es presentada casi sin cortes o cualquier otro tipo de intervención técnica, de modo que la audiencia acompaña la secuencia como si estuviese presenciando una agresión real. La larga duración de la secuencia, que se prolonga durante aproximadamente un minuto, provoca inquietud y malestar en la platea. La violencia explícita de esa escena remite a aquello que Radcliffe definió como horror.

Cuando Zé do Caixão se prepara para dar el golpe de misericordia - un puñetazo en la cara - la cámara se da vuelta inesperadamente para un reverse shot y el espectador es quien recibe el golpe. La cámara entonces muestra en extreme close up los labios de Terezinha sangrando y semiabiertos, de una manera sensual. Tumbándola en el sofá, Zé do Caixão besa su boca y, cuando vuelve la cara hacia la cámara, su sonrisa sangrienta se asemeja a la de un vampiro. El acto de violencia sexual ocurre fuera de escena y la violación se simboliza por la muerte de un canario, que Terezinha presiona en su mano durante el acto. En la próxima secuencia, ella se encuentra estirada en el sofá y la audiencia es invitada a asociar su figura lánguida con seducción y sentimiento de placer ante al ocurrido.

El problema de esa escena brutal no es la violencia en sí misma (que es una premisa del género de horror), sino el deseo sexual en asociación con la coacción y acosamiento del personaje femenino. Es decir, lo más difícil de interpretar en esta escena es la erotización de la violencia contra la mujer. Críticos han argumentado que escenas de violación en la ficción "no tiene un enlace directo con lo que se presume que es su defensa en la vida real" (Segal 68), ${ }^{6}$ y que la función de tales escenarios sería "galvanizar una respuesta constructiva para el verdadero problema del abuso en el mundo real" (Strossen 173). ${ }^{7}$ Además de lo anteriormente expuesto, otros críticos argumentan que las fantasías de violación constituyen en una parte

\footnotetext{
${ }^{5}$ En el original: "the heart-thumping stuff of the Gothic lore".

${ }^{6}$ En el original: "has no straightforward connection with what would be presumed to be its 'reallife' enactment".

${ }^{7}$ En el original: "galvanize constructive response to the problem of actual rape in the real world".
} 
arquetípica de nuestros cerebros, y en la imaginación, tal como en la ficción, "ninguna lesión corporal o humillación ocurrió [...]. Simplemente, lo que tiene que ser entendido es que lo ocurrido fue contra el deseo de la mujer" (Friday 4-5). ${ }^{8} \mathrm{De}$ hecho, presentar escenas de violencia erótica en la ficción no es lo mismo que sancionarlas en la sociedad, pero, discusiones sobre los efectos e impactos de la ficción en el mundo real y la historia de violencia contra las mujeres en textos ficcionales es un debate que aún no tiene resolución. A pesar que Zé do Caixão es confesadamente hostil con las mujeres, el uso de reverse shots en la escena, que el espectador es "atacado", imprime un aspecto formal que desafía interpretaciones simplistas sobre la relación directa entre sexo y género sexual en este filme. Dicho de otra forma, pensar que los espectadores van a identificarse con la violencia de Zé do Caixão y las espectadoras con el sufrimiento de Terezinha es un raciocinio simplista y restrictivo. El ataque al espectador oblitera la posibilidad de que los miembros de la audiencia se identifiquen con el agresor, el golpe en la cara representado por medio de la técnica de contraplano sugiere que nadie está a salvo de la brutalidad de Zé do Caixão.

La violencia del personaje está dirigido a cualquiera que se interponga entre sus objetivos y él. En el transcurrir del filme, Zé do Caixão arranca los ojos de un adversario y amputa los dedos de otro oponente con una botella rota - un trabajador que usa sus manos para ganarse la vida. Durante una pelea de bar, el sepulturero entierra una corona de espinas en la cara de un hombre y le da latigazos sin piedad a otro adversario. Las personas en el bar asisten a todo paralizadas, en estado de choque y horror. El hombre al que Zé do Caixão le da latigazos en el cuerpo y en la cara, hasta que se cae de rodillas, es negro (Genésio de Carvalho). La elección del actor y del instrumento de tortura para esta escena es particularmente simbólica, pues aborda el pasado histórico de Brasil, remitiendo a la cuestión de la esclavitud y de las tensiones raciales existentes en el país.

\footnotetext{
${ }^{8}$ En el original: "no bodily harm or humiliation took place [...]. It simply had to be understood that what went on was against the woman's will".
} 
Las representaciones de agresión sexual y racial en À meia-noite levarei a sua alma, y todos los otros crímenes que Zé do Caixão comete por creer que todo es posible en un lugar sin ley, contenían un grado de violencia que era desconocido por el público brasileño en la década de 1960. Buscando aquí una relación entre cine e historia, se plantea una correlación entre Zé do Caixão y formas de violencia sancionadas por el Estado. En esa conjetura, se puede leer el poder devastador del agente funerario como un síntoma del clima político que se instauró en Brasil, cuyo ápice fue el golpe de Estado el 1º de abril de 1964.

En la vida real, la dictadura brasilera prohibió la libertad artística y la expresión periodística. La represión política culminó el 13 de diciembre de 1968, cuando el presidente Costa e Silva firmó el Acto Institucional número 5 (AI-5), cerrando el Congreso Nacional y revocando derechos constitucionales de los brasileros. Esa acción, que llevó al poder al ala más reaccionaria del ejército, se conoció como "el golpe dentro del golpe". Entre las medidas promulgadas por el AI-5 estaba la suspensión del derecho de habeas corpus para cualquier acusado de crímenes contra la seguridad nacional. En la práctica, esto significó libertad vigilada de todos los ciudadanos y concesión de permiso para tortura por decreto presidencial, que se realizaba por agencias de seguridad como DOPS/Deops, OBAN y el infame DOI-CODI. En los años siguientes, la violencia sancionada por el Estado alcanzó sus peores niveles y llevó al desaparecimiento generalizado, persecución y exilio forzado de muchos brasileros.

Zé do Caixão continúa su saga en Esta noite encarnarei no seu cadáver (1968), un filme que escenifica modos de tortura idénticos a las atrocidades practicadas por policiales militares durante la dictadura, incluso colocar personas en espacios pequeños con serpientes y arañas y quemar partes de los cuerpos de prisioneros con productos químicos. Las imágenes de violencia y brutalidad que se destacan en esa película superan las representaciones de la película anterior. La censura instaurada prohibía, en nivel nacional, noticias sobre la disidencia política y conflicto social. También se suprimían de la prensa informaciones sobre rapto y tortura practicadas por agentes del gobierno, bien como protestas en las artes contra 
la dictadura. Agencias del gobierno federal determinaban si se liberarían los filmes lanzados, censurados o banidos por completo (Kushnir 58). El Servicio de Censura de Diversiones Públicas (SCDP) no prohibió totalmente la vehiculación de Esta noite encarnarei no seu cadáver, pero se le obligó a Mojica no sólo a cortar algunas escenas como también hacer un cambio significativo en su desenlace, de modo que Zé do Caixão se arrepintiese de sus actos.

Después del AI-5, la dictadura militar brasileña intensifica sus acciones represoras y el próximo filme de Mojica explota aún más las semejanzas entre los escenarios violentos de sus filmes de horror y los métodos de represión del gobierno. En Ideologia, cortometraje que es parte del largometraje $O$ estranho mundo de Zé do Caixão (1968), el agente funerario aparece disfrazado de su alter ego, el profesor Oãxiac Odéz. Su objetivo es realizar un experimento "científico" para probar que detrás de los disfraces de la educación y la cultura, los humanos son criaturas bestiales.

Para realizar esa tarea Oãxiac Odéz secuestra a una pareja, Alfredo (Osvaldo de Souza) y Vilma (Nidi Reis), y los aprisiona en el calabozo de su mansión. Entonces, él configura un circo de horrores, forzando a la pareja a ver escenas grotescas, mientras profiere charlas sobre la naturaleza de la condición humana-es una paradoja el modo como el profesor recurre a la violencia física para probar su hipótesis intelectual. Las escenas de violencia presentadas a la pareja de prisioneros son como actos interpretados, acontecen en un tipo de escenario donde las luces se esfuman antes del espectáculo y se apagan al final. Esa presentación, que tiene como base la producción dramática, subraya la naturaleza metaficcional del filme y aisla al público de las escenas de violencia (a pesar de que eso no proteja a los espectadores de su impacto visual). Para una platea brasileña, viviendo una dictadura, tal performance puede resultar en una interpretación política del discurso de horror. El director representa en esa escena técnicas de tortura que el gobierno militar practicaba. Por más que esos lugares fuesen escondidos de los ojos públicos, la tortura era un asunto prominente en la imaginación del pueblo brasileño. 
Bajo el pretexto de ser apenas un filme de terror, un género que resalta la violencia, Ideologia sigue siendo una obra particularmente notable debido a su título, por tratarse de una palabra de alto riesgo en aquella época, y por representar escenas de tortura que demostraban métodos bien conocidos de represión practicada por la policía política del gobierno. Esa combinación deja poco espacio para ambigüedades, significados ocultos o discursos codificados. Los procedimientos de tortura y los instrumentos presentados en Ideologia son los mismos usados en prisioneros políticos, incluyendo secuestro y encarcelamiento, "pau de arara", aislamiento, hambre, golpizas, abuso y estrangulación. 9

En este sentido, por demás de las ropas victorianas de Zé do Caixão, la representación de la violencia política refleja aquí una expresión brasileña del gótico, que se materializa a partir de un discurso de degeneración nacional, social y humana. En un contexto de violencia, manifestaciones callejeras y supresión artística, se pueden leer las películas de Zé do Caixão como indicadores históricos que coinciden con la institucionalización y el poder de la dictadura. Asimismo, se pueden conectar las representaciones de violencia y crueldad en las películas de Zé do Caixão, que aumentan a cada película, a las coyunturas históricas y a acontecimientos clave ocurridos de 1964 a 1968.

\section{¿Qué es el gótico brasileño?}

Se argumentó aquí que el gótico en el cine brasileño se caracteriza por medio de intervenciones cinematográficas puntuales. Películas brasileñas que pueden ser consideradas góticas muchas veces recurren a un desplazamiento de ideas como forma de debatir asuntos que no podían ser abordados de forma directa o cuyos problemas podrían ser fácilmente reconocidos y discutidos de modo más eficaz si transportados para un universo ficcional.

\footnotetext{
9 Para saber más sobre los métodos de tortura utilizados por los militares durante la dictadura brasilenã ver: Amnesty International (1984), Dassin (1986) y Kushnir (2004).
} 
Algunas películas de Walter Hugo Khouri y de José Mojica Marins se destacaron por ejemplificar el potencial de esa lectura gótica. La idea subyacente es que los discursos góticos son formas eficaces de representar contextos sociopolíticos, connotaciones metafóricas y contradicciones de los textos. En las películas de Khouri, los extraños efectos provenientes de las perturbaciones psicológicas de personajes presos en un universo burgués se manifiestan por medio de elementos y situaciones góticas, iluminando circunstancias relativas a la historia y a la cultura de Brasil. Las situaciones de indeterminación y obscuridad que caracterizan sus filmes los aproximan a aquello que Ann Radcliffe denominó narrativa de terror. En los filmes de Mojica, los efectos chocantes de una violencia brutal, envolviendo violación, golpizas y otros tipos de crueldad, caracterizan un gótico que hace referencia a las atrocidades e injusticias que se practicaron durante el período de la dictadura brasileña. El fuerte apelo visual de las películas, que muchas veces dejan a los espectadores sin reacción, se traduce en lo que Radcliffe designó como una narrativa de horror. Para ambos cineastas la tradición gótica es una fuente de inspiración. Sin embargo, aun valiéndose de elementos, imágenes y situaciones encontradas en el gótico angloamericano, los filmes analizados abordan traumas colectivos e individuales (relacionados a cuestiones de género, clase, raza, sexualidad y violencia) que remiten al contexto nacional, caracterizándose como expresiones únicas del gótico en el cine brasileño. 


\section{Bibliografía}

Amnesty International. Torture in the eighties. Pitman Press, 1984.

Bussing, Ilse Marie. "Sequestered Spaces and Defective Doors in Tales by Collins and Riddell.", Gothic: New Directions, special issue of Ilha do Desterro, vol. 1, n. 62, 2012, pp. 99-125.

Dassin, Joan \& Archdiocese of São Paulo. Torture in Brazil: A Shocking Report of the Pervasive Use of Torture by Brazilian Military Governments, 1964-1979. Traducción de Jaime Wright. Vintage Books, 1986.

Ellis, Kate Ferguson. The Contested Castle: Gothic Novels and the Subversion of Domestic Ideology. University of Illinois Press, 1989.

Friday, Nancy. Women on Top. Simon \& Schultz, 1991.

Garret, John. Gothic Strains and Bourgeois Sentiments in the Novels of Mrs. Ann Radcliffe and Her Imitators. Ayer Co Pub., 1980.

Hogle, Jerold E. "The restless labyrinth: Cryptonomy in the Gothic novel." Gothic Critical Concepts in Literary and Cultural Studies, edited by Fed Botting and Dale Townshend. Routledge, 2004. p. 145-166.

Hume, Robert. "Gothic versus Romantic: A Revaluation of the Gothic Novel." PMLA, vol. 1, n. 84, 1969, pp. 282-290.

Kushnir, Beatriz. Cães de guarda: Jornalistas e censores, do AI-5 à Constituição de 1988. Boitempo, 2004.

Palmer, Pauline. "Lesbian Gothic: Genre, Transformation, Transgression." Gothic Studies, v. 1, 2004, pp. 118-130.

Platzner, Robert L. “'Gothic versus Romantic': A Rejoinder.” PMLA, v. 2, n. 86, 1971, pp. 266-274.

Pucci Jr., Renato Luiz. O equilíbrio das estrelas: Filosofia e imagens no cinema de Walter Hugo Khouri. Annablumme, 2001.

Radcliffe, Ann. "On the Supernatural in Poetry." The New Monthly Magazine. 2020. Gothic Digital Library@UFSC.

https://repositorio.ufsc.br/handle/123456789/208925

Segal, Lynne. "Only the literal: The Contradictions of Anti-Pornography

Feminism." More Dirty Looks: Gender, Pornography and Power, edited by Pamela Church Gibson. British Film Institute, 2004. pp. 59-71.

Serravalle de Sá, Daniel. "Zé Do Caixão y el gótico brasileño de José Mojica

Marins." Catedral Tomada, vol. 5, n. 8, 2017, pp. 104-119. 
Snodgrass, Mary Ellen. Encyclopedia of Gothic Literature. Infobase, 2009.

Strossen, Nadine. Defending Pornography: Free Speech, Sex, and the Fight for Women's Rights. New York University Press, 2000.

Varma, Devendra P. The Gothic Flame: Being a History of the Gothic Novel in England: its Origins, Efflorescence, Disintegration, and Residuary Influence. Barker, 1957. 